\title{
Visual Sensory Stimulation for Toddler in Hikari Kids Club Children Care Padang
}

\author{
Zulminiati \\ Department of Early Childhood Education \\ Universitas Negeri Padang, Padang, Indonesia \\ bundazulminiati@gmail.com
}

\begin{abstract}
This study aims to find out sensory stimulation of visual in the Children Care Hikari Kids Club Padang. The research was conducted at Hikari Kids Club Child Care Park in Padang City in July 2017. This research used descriptive research with qualitative approach. Data collected through observation, interviews, and documentation. Data were analyzed using Miles and Huberman data analysis technique. The result of this study found that stimulation by nanny to toddler in Hikari Kids Club Padang Children Care has not been optimally done in giving sensory stimulation because of the limitations of the tool and the teacher's understanding in the use of sensor sensory media.
\end{abstract}

Keywords--toddler; sensory vision stimuli; children care.

\section{INTRODUCTION}

Early Childhood Educationis an effort to provide stimulation by parents, carers, and community to cultivate the physical-motor, religion and moral, cognitive, linguistic and social-emotional aspects of children aged 0 to 6 who have intellectual intelligence, as well as various arts and skills needed [1]. Another opinion is that early childhood education is the level of education before basic education that seeks to provide guidance to children from birth up to six years of education stimulation to help the growth and development of physical and spiritual child, in order to have readiness to enter the basic education [2]

Early childhood education is to guide children based on the underlying theory of what and how children learn, the curriculum, and what experiences children gain through their ongoing education [3].Early children are kids aged 0 to 6 years, consisting of infancy, toddlerhood, and preschool, each period showing the development of each different. This is influenced by the provision of stimulation by adults to children (Wiyani, 2016). Regulations of Ministry of Education and Culture number 137 year 2014 [4] on Early Childhood Education Standard is aimed at ensuring the quality of early childhood in order to provide a basis for: 1) To stimulate education in assisting the growth and development of children in accordance with the level of child development achievement, 2) Optimizing the development of children holistically and integrative, 3) Preparing knowledge, attitude, and skills of children.
Children Care is a form of Early Childhood Education institute of non formal education program that organizes education, care and social welfare for children from birth up to 6 years and priority from birth to 4 years old. Children care is a child welfare program that can provide services holistically and integratively. Holistic is all the needs of children to grow and develop such as; health, nutrition, nurturing, and child care are served by the day-care center. Integrative means that all childcare institutions work with partner institutions and coordinate with relevant agencies. Management of learning carried out one of the learning activities to play motor sensory.To see the level of developmental achievement associated with the sense-of-sightin viewing skills such as: similarities and differences, shapes, colors, and objects [4].

Another opinion of the children care is a social welfare institution that provides replacement services in the form of upbringing, care and education for toddlers as long as the child is left working by their parents [5].

Based on preliminary research through oservation, interviews and documentation, then found problems in children care of Hikari Kids Club Padang. The research questions are 1) Are there any visual sensory stimulation learning activities in children care of Hikari Kids Club Padang?; 2) What is an educative game tool for the sensory stimulation of vision in learning in children care of Hikari Kids Club Padang?; 3) How to use game tools in learning activities in children care in Hikari Kids Club Padang?.

\section{METHODOLOGY}

The research was held at children care in Hikari Kids Club Padang focused on sensory sight stimulation for toddler. The research took place from July to September 2017. This research is conducted preliminary research from development research that is running now, with the aim to see the existing phenomenon in the field. The research was carrie out by the research team as a direct observer, as well as making the results of the research, then involving the teachers in children care at Hikari Kids Club Padang. The method of data collection is by observing the activities undertaken by the teacher or caretaker with the child, by making a record. Interview with the meeting at each meeting, then the data is described. Documentation on the situation and implementation of learning at children care, Hikari Kids Club Padang. The data obtained then processed into a research results. 


\section{RESULT AND DISCUSSION}

Children care in Hikari Kids Club Padang was established with the main mission to serve children grow and develop according to their potential, then help the busy parents that have no time to take care of their children. The number of personnel of caretakerat the children care in Hikari Kids Club Padang are 6 people, and there is no materi about early childhood education available like in kindergarten. Number of children are 20 people. Building area 36 type house, consists of 2 bedrooms, 1 room free space, kitchen and bathroom. Learning activities start from Monday to Friday in a full day.

This is an Observation results at children care at Hikari Kids Club Padang on table I, and the results of interviews with teachers on table II.

TABLE I. OBSERVATION RESULTS

\begin{tabular}{||l|l|l|}
\hline No & \multicolumn{1}{|c|}{$\begin{array}{c}\text { Focus of } \\
\text { Observation }\end{array}$} & \multicolumn{1}{c|}{ Results } \\
\hline 1 & Teacher/caretaker & $\begin{array}{l}\text { The caretaker controls in the other room } \\
\text { children 2-3 year-old was sleeping on his } \\
\text { own mattress, there was one child not } \\
\text { sleeping under the care of a caretaker, } \\
\text { where the caretaker went he followed } \\
\text { while carrying his bag. The caretaker } \\
\text { introduced me with a handshake and } \\
\text { mentioned his name. }\end{array}$ \\
\hline 2. & Children & $\begin{array}{l}\text { Since the first day of observation, the } \\
\text { children in children care atHikari Kids } \\
\text { Club Padang are happy to hear stories } \\
\text { from the caretakers. They look happy with } \\
\text { the learning activities they do with } \\
\text { caretakers. There are babies who sleep in } \\
\text { the room there is being carried by a } \\
\text { caretaker. } \\
\text { On the second day, some children are seen } \\
\text { sleeping in the room, there is a wake up } \\
\text { stroll while following the caretaker. } \\
\text { Children play unloading pairs, }\end{array}$ \\
\hline
\end{tabular}

TABEL 2. RESULTS OF INTERVIEWS

\begin{tabular}{||l|l|l|}
\hline No & Question & Answer \\
\hline 1 & $\begin{array}{l}\text { Whether in the schedule of the } \\
\text { mother's learning activities there is } \\
\text { sensory stimulation activity for the } \\
\text { child? }\end{array}$ & Not yet. \\
\hline 2 & $\begin{array}{l}\text { Do mothers use game tools to } \\
\text { stimulate child sensory }\end{array}$ & Not yet. \\
\hline 3 & $\begin{array}{l}\text { Do you understand how to use a child } \\
\text { sensory stimulation game? }\end{array}$ & Not yet. \\
\hline
\end{tabular}

Based on the results of the documentation at children care of Hikari Kids Club Padang, indicate that sensory stimulation activities are not scheduled. According to Depdikbud [4] the activity schedule of children aged 3 months to 24 months there is a child's stimulation schedule according to the age of development related to the senses of sight, hearing, touch, and smell. Such as the stimulation of listening to prayers, songs, and other sounds. Stimuli sensory vision is like a skill to see the similarities and differences, shapes, colors, objects. Then stimulation in motor training, language, and socialization. For infant or toddler activities, schedules are flexible, stimulation can be given in the form of joint care.

Based on observation and interview data there is one game tool to stimulate the eyesight of the dependent child, but not used by the caregiver in learning to stimulate the vision of child.Depdikbud [4] To help the achievement of optimal learning, media and learning resources are needed in accordance with the activities carried out. Children care in providing services so that the child entrusted gets stimulated according to the needs and age of the child, one of which provides support to the child to be able to learn through playing by using the teacher's own game tool to support the sensory activities, so that children have useful experience in developing the whole potential of the child, because one of the functions of the game is activating all the five senses. Mulyasa [5] says children gain knowledge through sensory that is through seeing, hearing, touching, sensory children will respond to any stimulation it receives. Therefore, the learning provided by the caregiver should provide stimulation that can stimulate every child sensori optimally. Glenn Doman [6] says brain growth and development is a dynamic and constantly changing process. Growth of infant or toddler brain to accelerate its development by stimulating his visual, auditive, tactile with increased frequency, intensity, and duration aligned with the regularity of brain growth. The brain grows because it is used. Stimulation should be given intentionally, the more the brain is used the more honed the ability of the child. Susanto [7] Stimuli given will optimally affect the child if given appropriately to the child's condition in all aspects of child growth. The ability of the brain is influenced by the activity of neurons and not spontaneous, but is determined by the quality and frequency of stimulation received by the child's senses. The first year of child life stimulates the physical structure of the child's brain and is difficult to repair in later life. According To Yamin [8] When a child learns a need for a perception of one's vision, the ability is internal in the brain to analyze the information it receives.

Based on the analysis data, children has not been optimally provided by the teacher, this is evident from the schedule of learning activities at children care of Hikari Kids Padang. There are tools the teacher has not been able to use. In terms of Wiyani [9] early childhood education institutions are the second environment for children, such as in children care, children will interact with teachers and peers so that will affect the development of children, stimulation provided by the teacher will optimize the development of children.

\section{CONCLUSIONS AND RECOMMENDATIONS}

Based on the results of research and discussion, it can be concluded that: 1) Learning activities sensory stimulation for children not scheduled in learning activities every day; 2) The game equipment for sensory stimulation is one but not yet used, there is still a lack of equipment provided for sensory stimulation at the Hikari Kids Club Padang TPA; 3) Teachers have no early childhood background, so are less able to use tools for sensory stimulation in children. 
Based on these conclusions, it is suggested that 1) Teachers need to be given training on how to provide sensory stimulation to toddler children; 2) Research continued with development research, making guides and tools for sensory stimulation in toddler children; 3) Teacher collaboration should be improved.

\section{References}

[1] Wiyani, Novan. 2016.Konsep Dasar PAUD. Jakarta: Gava Media.

[2] Ulfah,Fari.2015.Manajemen PAUD : Pengembangan jejaring Kemitraan Belajar.Yokyakarta: Pustaka Pelajar.

[3] Morrison, George S. 2012.Dasar-dasar Pendidikan Anak Usia Dini. Edisi kelima. Jakarta: PT Indeks.

[4] Depdikbud. 2015.Petunjuk Teknis Penyelenggaraan Taman Penitipan Anak. Jakarta.

[5] Mulyasa. 2012.Manajemen PAUD. Bandung: Rosda Karya.

[6] Glenn,Doman. 2009.Yes, Your Baby Is A Genius (bayi anda sungguh jenius)Kembangkan dan Tumbuhkan Sejak Lahir.Terj. Prasetia Adi Saputra. Jakarta: Tigaraksa Optima Perkasa.

[7] Susanto, Ahmad.2017 PAUD Konsep dan Teori. Jakarta: Bumi Aksara.

[7] Susanto,Ahmad.2011.Perkembangan AUD Pengantar dalam berbagai Aspeknya.Jakarta: Kencana Prenada Media Group.

[8] Yamin,Sanan. 2012. Panduan PAUD. Jakarta: Gaung Persada Group.

[9] Wiyani,Novan.2017.Manajemen PAUD Berdaya Saing. Yokyakarta: Gava Media 